\title{
THE OTHER SIDES OF PESANTREN: \\ MAGICAL PRACTICES AROUND PESANTREN IN BANTEN
}

\author{
Fahmi Irfani \\ Universitas Ibn Khaldun Bogor \\ Kedungbadak, Tanah Sereal, Bogor, West Java, Indonesia \\ E-mail:fahmiirfani@fai.uika-bogor.ac.id \\ Azkia Muharom Albantani \\ Universitas Islam Negeri Syarif Hidayatullah Jakarta \\ East Ciputat, South Tangerang, Banten, Indonesia \\ E-mail:azki@uinjkt.ac.id
}

\author{
Ahmad Suhendra \\ Babakan, Tangerang, Banten \\ E-mail:asra.boy@gmail.com \\ Hafizhah Masnin \\ Al-Zuhri Institute of Higher Learning \\ Wisma Indah, Singapore \\ E-mail:hafizhah@zuhri.com.sg
}

Sekolah Tinggi Ilmu Syariah Nahdlatul Ulama Nusantara Tangerang

\begin{tabular}{c|c|c}
\hline Received: & Revised: & Approved: \\
26/09/2021 & $19 / 10 / 2021$ & $17 / 12 / 2021$ \\
\hline
\end{tabular}

DOI : 10.32332/akademika.v26i2.3694

\begin{abstract}
Pesantren in Banten have different characteristics compare to other pesantren in Indonesia. Discussing about this Province, most people believe that Banten is of a Province in Indonesia which is famous with its Ulama, Kyai, Santri and Pesantren. This research discusses about practices of magical culture in Pesantren around Banten. The research model used in this study is qualitative-descriptive. Historical studies are used to present a narrative and chronological presentation of the storyline of a discussion. Results showed that stereotypes and beliefs arise because Islamic values have traditionally been rooted in most Banten citizens, culturally and ritually. One of the characteristic of Pesantren in Banten is that every santri are taught with magic, silat and tasawuf knowledge. Those are characteristics that have always been a matter of discussion, people believe that there are practices of magic in every pesantren in Banten. Some sources call Banten a center for the occult sciences, as well as being known as a religious area. Magical practice is still considered important for the people of Banten, especially those living in rural areas to solve practical problems in their social life. In addition, the existence of jawara and pesantren has created its own cult which is somewhat different from the dominant culture of Banten society.
\end{abstract}

Keywords : Banten, culture, magical knowledge, magical practices, and santri 


\section{A. Introduction}

Islamic boarding school (henceforth: pesantren) is one of the educational institutions in Indonesia. Before Indonesia obtained its independence, pesantren has existed and given a huge contribution to this country, as written in the history that students (henceforth: santri) had a huge contribution in gaining and fighting for Indonesian independence ${ }^{1}$. Pesantren continues to evolve and undergo modernization, although some pesantren remain adhering to traditional pesantren values. ${ }^{2}$ Banten is one of the provinces which is located in the west side of Java Island. ${ }^{3}$ Most Banten citizens are Muslim. However, some local citizens still embrace their ancestor's beliefs (such as the Baduy tribe). The biggest ethnic group that lives in this area is the Sundanese. Most of them live in the South of Banten while for West of Banten is lived by citizens who emigrated from Cirebon. The Sundanese language used in Banten is considered the ancient Sundanese Language. Most people believe that Banten is the province of ulama, kiayi, santri, and pesantren. Those stereotypes and beliefs arise because Islamic values have been rooted strongly in most Banten citizens traditionally, culturally, and ritually. Moreover, Banten is also famous as a place to learn Kanuragan and Debus's power. The influence of Islam had extended across Banten province by the 16th century, as evidenced by the foundation of the Sultanate of Banten Girang around 1520-1820 M.4 Through insurrection, Prince Sabakingking, son of Sunan Gunung Djati, established the Sultanate of Banten in 1552. Then, he successfully conquered Banten Girang.

Daniel L. O'Keefe ${ }^{5}$ explained that people's belief in supernatural powers and the practice of magic has existed since ancient times. Magic is not only found in the stone age and primitive societies but can also be found almost every time in every society everywhere and magic appears in many cultures in the world, including in Banten. Magic is a real social phenomenon, both in primitive and modern societies. Therefore, almost everyone believes that magic exists and occurs in life. Magic can build trust in uncertain situations. ${ }^{6}$

Banten is important in the world of magic. Martin van Bruinessen ${ }^{7}$ said, that Banten has a strong reputation as a haven for magic practices. The most concrete example of the magic tradition in Banten that has existed since the sultanate era can be seen in the presence of Debus. The teachers or sheikh of debus in their performances involved a whole series of magical practices. ${ }^{8}$ Banten culture which is very close to Islamic cultural values has created its own culture which can be said to be cultural

${ }^{1}$ M. Falikul Isbah, "Pesantren in the Changing Indonesian Context: History and Current Developments," QIJIS (Qudus International Journal of Islamic Studies) 8, no. 1 (June 22, 2020): 65.

2 Jamhari Jamhari, "New Trend of Islamic Education in Indonesia," Studia Islamika 16, no. 2 (August 31, 2009), accessed October 29, 2021, http://journal.uinjkt.ac.id/index.php/studiaislamika/article/view/482; Andik Wahyun Muqoyyidin, "Islam Jawa, Distingsi Tradisi, Transformasi Spirit Profetik, Dan Globalisasi," Akademika : Jurnal Pemikiran Islam 21, no. 1 (2016), https://e-journal.metrouniv.ac.id/index.php/akademika/article/view/458.

${ }^{3}$ Koentjaraningrat, “'Manusia Dan Kebudayaan Di Indonesia,'” Djambatan (2010).

${ }^{4}$ Fahmi Irfani, "Jawara Banten, Sebuah Kajian Sosial, Politik Dan Budaya" (UIN Syarif Hidayatullah, 2011).

${ }^{5}$ Ralph W. Hood and Daniel Lawrence O'Keefe, "Stolen Lightning: The Social Theory of Magic," Sociological Analysis (1982).

${ }^{6}$ John Rawls, Bronislaw Malinowski, and Robert Redfield, "Magic, Science, and Religion and Other Essays.," The Philosophical Review (1948).

7 Martin Van Bruinessen, Kitab Kuning, Pesantren Dan Tarekat, Yogyakarta, Gading Publising, 2015.

8 Ibid. 
assimilation and cultural diffusion between local culture and Islam. The combination of Islamic culture and local culture is called a cultural complex, while the environment of that cultural element is called a cultural circle. ${ }^{9}$

Dhofier ${ }^{10}$ said that Banten was once an Islamic kingdom. The position of kyai and pesantren in Banten has a significant social structure within Banten society. This is because the position of the kyai is an extension of the sultan's hand in Islamization in Banten which has led to the emergence of pesantren led by the kyai. The kyai is a teacher who transmits Islamic knowledge to the students studying at the pesantren.

In the 16th century, Islamic boarding schools (pesantren) in Banten were known as institutions that did not only teach Islamic science but studied aspects of magic or ngelmu (learning magical science) or what is better known as white magic. According to Harsja W. Bachtiar ${ }^{11}$, abilities in the magical realm and belief in supernatural powers are not confined to dukun (shaman), but many santri from pesantren also perform magic.

Banten is known as one of the areas that are strong with its magical world. Therefore, several writings carry out special research on magic in Banten. One of the articles is Humaeni's writings ${ }^{12}$ titled "The Local Tradition of Magical Practices in Banten Society". This paper contains a cultural phenomenon regarding magical practices in the Muslim community of Banten which still exists today. This study uses an ethnographic method based on an anthropological approach. The magical practice has become a cultural identity for the people of Banten. Some sources mention Banten as a center for the occult sciences, as well as known as a religious area. Magical practice is still considered important for the people of Banten, especially those living in rural areas to solve practical problems in their social life ${ }^{13}$.

The other article is Rohman's research (2013)14 entitled "The Result of a Holy Alliance Debus and Tariqah in Banten Province", which examines the practice of debus and its function for the people of Banten today. The question outlined in this article is how the current practice of debus is considered an integral part of Banten tradition. There are several studies on debus in Banten and other places in Indonesia. Most of them are anthropological studies. Very little attention has been given in-depth to the studies of debus that are practiced by the people of Banten. In fact, debus has evolved as a show of invulnerability. It is even more than just a show of invulnerability as in Aceh as described by Snouck in the late nineteenth century. The practice of debus combined with the current aspects of the order seems to include many new attributes.

Hudaeri ${ }^{15}$ wrote a study on "Tasbih and Machete: The Study of the Charisma of Kyai and Jawara in Banten". This research resulted in the discovery that the position of kyai in Banten society is a social elite in the field of religious social and community leaders who has a role that directs and organizes social life. Meanwhile, the position of the

9 Irfani, “Jawara Banten, Sebuah Kajian Sosial, Politik Dan Budaya."

10 Zamakhsyari Dhofer, "Tradisi Pesantren: Studi Pandangan Hidup Kiai Dan Visinya Mengenai Masa Depan Indonesia," (Jakarta: LP3ES) (2011).

11 Ronald Provencher et al., "Readings on Islam in Southeast Asia," Journal of the American Oriental Society (1990).

12 Ayatullah Humaeni, "The LocaL Tradition of Magical Practices in Banten Society," ElHarakah (2012).

13 Ayatullah Humaeni, "Penggunaan Magic Dalam Politik Lokal Di Banten," Masyarakat, Kebudayaan dan Politik (2014).

14 Rohman, "The Result of a Holy Alliance: Debus and Tariqah in Banten Province," Afkaruna: Jurnal Ilmu-Ilmu Keislaman 9, no. 1 (2013).

${ }^{15}$ Mohamad Hudaeri, "Tasbih dan Golok," ALQALAM (2003). 
warrior (henceforth: jawara) as the leader of the indigenous institutions of the community becomes a respected figure when he becomes a social leader for his mastery of economic resources. Kyai takes important roles as a community leader (kokolot), Quran teacher, book teacher, order teacher, "hikmah" (occult) science teacher, and as preacher. Meanwhile, the social role of jawara is primarily oriented on the processing of physical and "inner" powers, with traditional roles such as jaro (village head or lurah), teacher of martial art (silat) and "inner" or magical science, and security units. The position, role, and network of kyai and jawara have established their own cultures, which are distinct from Banten society's mainstream culture. ${ }^{16}$ As a result, both not only describe the figure, but have also evolved into a community with different values, conventions, and perspectives. That is the kyai and jawara's subculture. ${ }^{17}$

It can be observed from the literature and studies in the preceding description that there have been some researches on magical practices in Banten, but they have not concentrated on magical rituals done or practiced in pesantren in Banten. As a result, this research can be continued and offers research novelty value.

\section{Conceptual Framework}

When discussing pesantren, most people believe that it is a place to seek and get Islamic knowledge. Pesantren is identical with kiyai, santri, turats (classical Islamic book), mosque and pondok (place) where santri lives. ${ }^{18}$ Magic as an element and knowledge exists in pesantren. This occurrence, however, is distinct from what happened in Banten. At least there are reasons why pesantren is also famous for its magic in the culture of santri. Pesantren first appeared in Banten in the 16th or 17th centuries. According to Serat Centini, there was a pesantren in Gunung Karang, on the west side of Pandeglang, during that century.

In contrast, Martin van Bruinessen stated that there was not any pesantren in Banten until the 18th century. He made such a statement because he believes that during the 16th and 17th centuries, Islam was taught through mosques, palaces, and tarekat or tasawuf. 19 Magical activities to gain specific powers were located around the sacred burial in Gunung Karang, Pulosari, and Panaitan (an ascetic site). Pesantren in Banten began to emerge towards the end of the 18th and early 19th centuries, according to Bruinessen. ${ }^{20}$ Pesantren emerged as a form of resistance against Dutch colonial rule.

Based on the explanation above, even though both Bruinessen and Serat Centini have different opinion, but it can be seen that during the $16^{\text {th }}$ century Banten has been known for its pesantren as an educational institution which is used not only to transfer the knowledge of Islam but also to learn magical knowledge/ability called as ngelmu or also known as white magic. According to Harsja W. Bachtiar ${ }^{21}$, the ability and beliefs

16 Ayatullah Humaeni, "The Basic Concepts of Magic And The Kinds of Magic in Banten Society," Al-Fath 03, no. 01 (2009).

17 Siti Durrotun Nafisah, “Melacak Sumber-Sumber Penggunaan Ayat-Ayat Pengobatan Dalam Kitab Shams Al-Ma'ārif Al-Kubrā," Al Itqon: Jurnal Studi Al-Qur'an 5, no. 1 (2019).

18 Yanwar Pribadi, "Pesantren Pluralis: Peran Pesantren Ngalah Dalam Mengembangkan Nilai-Nilai Pluralisme Di Tengah Masyarakat Yang Multikultural, by M. Muntahibun Nafis," Bijdragen tot de taal-, land-en volkenkunde / Journal of the Humanities and Social Sciences of Southeast Asia 174, no. 2-3 (January 1, 2018): 333-337.

${ }^{19}$ Fahmi Irfani, "Islam Dan Budaya Banten," Buletin Al-Turas 16, no. 1 (2010): 202-203.

${ }_{20}$ Bruinessen, Kitab Kuning, Pesantren Dan Tarekat.

21 Provencher et al., "Readings on Islam in Southeast Asia." 
toward magical aspects in Indonesian people are not only restricted to shaman (henceforth: dukun) but also to santri and pesantren which practice it (magic). As previously said, Padepokan Persilatan (places to study traditional martial arts) was cemented during the 17th century. During that time, pesantren and padepokan as a place for magical practices formed jawara and santri as Banten culture. In addition to the factors mentioned above, one of the reasons why pesantren is incorporated as part of jawara and santri's culture is because pesantren is the center of white magic that jawara and santri obtained in Banten.

Mystical knowledge is acquired without the use of the senses or by calculating ratios, but it is acquired through the feeling and heart. Abstract-supra-rational objects, such as the supernatural, God, angels, heaven, hell, and jinn, are the object of mystical knowledge. In general, mystical knowledge is acquired through an activity known as riyadhah (training). It is a way in which people might receive enlightenment and knowledge.22.

Magical power is considered as a need for jawara and santri in Banten. Jawara and santri will be unable to lead and associate in society without the use of magic. Banten residents believe that a jawara who lacks magical abilities is not a true jawara. The same beliefs also apply to santri who will be the next kyai. Santri are those who can improve and develop their magical power along with their hikmah knowledge. To get the magical power, jawara and santri become students of a kyai who is believed as the source of that magical power.

The knowledge of wisdom, according to Imam Abi al-Abbas Ahmad bin Ali alBunni's book Manba 'Ushul al-Hikmah ${ }^{23}$, cleans the spirits from the impurities of godliness like soap cleans clothes. A soul that has attained enlightenment yearns to reach the spirit realm. The soul will incline to the lusts of the dead body to revive the soul and save it from the consequences of lust and the cords that tie people who do not have the knowledge of wisdom.

The existence of santri could not be separated from the roles of kyai and their pesantren ${ }^{24}$, because the existence of santri and jawara come from Pesantren. Pesantren has two different types of santri; The first kind is the santri who has the ability, talent and knowledge to learn Islamic knowledge, and the other one has the ability and talent to learn Indonesian traditional martial art (silat). During their learning process, students who have the ability and are interested in learning about religion are called as Santri, while those who are interested in Silat and magical power are called as jawara. The difference between Jawara and Santri can be seen from the way they learn the power. Santri focuses on learning religious knowledge, while jawara focuses on mastering the ability of martial arts. Kyai has a role as the source of getting those magical spells. Kyai transfers those magical power to jawara and santri. ${ }^{25}$ Kyai serves as santri's source of magical strength, transforming magical powers such as Kanuragan, Brajamusti, and Invulnerability power into santri. Kyai and their santri are affected by the emotional link between teachers and students; yet, their relationship may be greater than the one between teachers and students.

22 Hambali, "Pengetahuan Mistis Dalam Konteks Islam Dan Filsafat Ilmu Pengetahuan," Substantia: Jurnal Ilmu-Ilmu Ushuluddin 13, no. 02 (2011).

${ }^{23}$ Imam Ahmad bin Ali Al- Bunni, Manba' Ushul Hikmah (Bairut: Darul Fikr, n.d.).

${ }^{24}$ Ronald Lukens-Bull, "Madrasa By Any Other Name: Pondok, Pesantren, and Islamic Schools in Indonesia and Larger Southeast Asian Region," Journal Of Indonesian Islam 4, no. 1 (June 1, 2010): 1.

${ }^{25}$ M.A. Tihami, "Kiyai Dan Jawara Di Banten, Studi Tentang Agama, Magi, Dan Kepemimpinan Di Desa Pesanggrahan Serang Banten" (University of Indonesia, 1992). 
Based on those aspects, pesantren is known as the root or source of magical power for santri and jawara, and it is also known as a place to facilitate magical power for santri and jawara. Besides teaching religious knowledge, pesantren also legates magical power to its santri hereditary. That magical inheritance becomes one of the pesantren's distinguishing characteristics in Banten, and it is a reason that allows pesantren in Banten to develop more quickly. The development of magical practices in Banten became one of the demands in the colonial era. Santri were endowed with the magical power to be able to carry out revolts against Dutch colonialism, commanded by kyai. ${ }^{26}$ Furthermore, that magical ability was also utilized to help them live during the time. Having magical ability would be useful to survive in Banten, especially between the 17th - 19th centuries, when the situation was prone to criminal deeds. Jawara Banten and magical activities in Banten arose as a result of these factors.

The forms of ngelmu (knowledge) that are often used by jawara are brajamusti (the ability to make powerful blows), ziyad (the ability to control something from a distance), amulets or rajahs (the ability to seek authority, wealth or someone's love), putter gilling (the ability to roll back or be loved by someone, or find lost or escaped people), elmu (the ability to subdue venomous or dangerous animals) and so on. ${ }^{27}$

Hudaeri 28 in his writing classifies kyai in Banten based on their roles. The kyai are often classified into "kyai Kitab" and "kyai hikmah". Kyai Kitab is addressed to kyai who teaches a variety of Islamic textual disciplines, that are referred to as turast or the 'yellow book'. 'Kyai hikmah' refers to a kyai who practices Islamic magic. They usually teach wirid, zikr, and ratib, for practical purposes, including medicine, supernatural powers, and authority. However, the differences do not separate in practice. The socioreligious roles of the kyai in Banten can be detailed in several parts ${ }^{29}$. First, the role of the earliest kyai was to teach the students the recitation of the Qur'an well. Second, a santri who was fluent in reading the verses of the Quran began to become acquainted with the classical books. The fame of a kyai and pesantren is determined by the ability to understand the content and provide teaching at the level of these classical books. Third, a charismatic kyai also teaches tarekat practices in addition to classical texts. Fourth, the kyai who becomes a murshid of tarekat is not only known as a leader or teacher of tarekat but is also known as a teacher of wisdom or magic. Until now, pesantren in Banten have a well-known reputation as a place for the occult sciences. Fifth, kyai do not only stay in a pesantren to teach classical books to their students or settle down in a place where their people will come to seek advice, prayers, and other practical needs, 30 but they also actively conduct religious lectures to the wider community, so that they are called preachers $\left(d a^{\prime} i\right){ }^{31}$

26 Tim PPIM UIN Jakarta, "Strengthening Civic Values Through Pesantren and Madrasah," Studia Islamika 15, no. 2 (August 31, 2008), accessed October 29, 2021, http://journal.uinjkt.ac.id/index.php/studia-islamika/article/view/535.

27 M.A. Tihami, “Kyai dan Jawara di Banten” (Indonesia University, 1991); Marcel Mauss, A General Theory of Magic (New York: W.W. Norton \& Company, 1975).

28 hudaeri, "Tasbih dan Golok."

${ }^{29}$ Hasan Shadily (ed.), "Magi," Ensiklopedi Nasional Indonesia (Cipta Adi Pustaka, 1990).

30 Mulhollanc. John, "Magic," The World Encyclopedia (Field Enterprises Educational Corp, 1964); Koentjaraningrat, Beberapa Pokok Antropologi Sosial (Jakarta: Dian Rakyat, 1985); C.A. van Peursen, Strategi Kebudayaan (Yogyakarta: Kanisius, 1988); Mariasusai Dhavamony, Fenomenologi Agama, Kelompok S. (Yogyakarta: Kanisius, 1995).

31 Muhammad Latif Fauzi, "Traditional Islam in Javanese Society: The Roles of Kyai and Pesantren in Preserving Islamic Tradition and Negotiating Modernity," Journal of Indonesian Islam 6, no. 1 (June 1, 2012): 125; Abdallah Abdallah, "State, Religious Education, and 
Magic, according to Ki Agung Pranoto, ${ }^{32}$ is the science of inner development, meditation, resting the cerebrum functions, and allowing the cerebellum to take over. The mind becomes still and activates the supernatural powers that exist in the human body. The more solemn this process is, the lighter the body will become. The body's metabolism will change. The cells divide and eventually emit certain particles in the form of rays out of the body and can be controlled like a bullet. Ki Agung Pranoto believed that one day both black and white magic would become part of science; mysterious mysteries will be revealed.

\section{Research Method}

The research model used in this study is qualitative-descriptive. Historical studies are used to present a narrative and chronological presentation of the storyline of a discussion. One thing that distinguishes a story whether it has been done through the stage of historical research or not lies in the analysis submitted by historians or chroniclers. In this writing, a discussion of history will be presented which is not only narrative-chronological but also accommodates interpretations to create novelty in historical writing.

There are several steps that have been conducted in this research. Data search of heuristics is the initial step done in this investigation. The two cores of this study are defined in this article as library research and field research. According to Kuntowijoyo, 33 written documents are elements that historians would later utilize to interpret history. In addition to library research, the researcher visited several pesantren that were pertinent to the study. A source search was undertaken through interviews with numerous kyai's personalities in Banten to supplement the findings from the literature study. The participants in this article are two kyai; Kyai Fahad and Kyai Mahrusillah. Both figures and kyai practitioners are those who teach magic in the pesantren.

Once the reference sources and interview sources have been collected, it is then organized by source criticism. The novelty of the author's renewable discoveries is reflected in the interpretation outcomes. In order to achieve a complete and chronological form, it is necessary to write down the findings.

\section{B. Magical Practices in Banten's Pesantren}

Generally, there are two models of pesantren which developed in Banten. The first is "Pesantren Salafi (traditional pesantren)" and the second is "Modern Pesantren"34. Pesantren Salafi or also known as bale rombeng has a huge contribution towards the development of magical power in Banten. From this model of pesantren, many jawara

Prevention of Violent Extremism in Southeast Asia," Studia Islamika 26, no. 2 (August 13, 2019), accessed October 29, 2021, http://journal.uinjkt.ac.id/index.php/studiaislamika/article/view/12204.

32 Ki Agung Pranoto, Saatnya Dukun Bicara: Tinjauan Kritis Terhadap Takhayul Dan Kebatinan (Yogyakarta: Galang Press, 2000).

${ }^{33}$ Kuntowijoyo, "Pengantar Ilmu Sejarah," Jurnal Ilmu Sejarah dan Kebudayaan (2013).

${ }^{34}$ Hatim Gazali and Abd. Malik, "Pesantren and the Freedom of Thinking: Study of Ma'had Aly Pesantren Sukorejo Situbondo, East Java, Indonesia," Al-Jami'ah: Journal of Islamic Studies 47, no. 2 (December 20, 2009): 295-316; Ali Mas'ud, Ah. Zaki Fuad, and Achmad Zaini, "Evolution and Orientation of Islamic Education in Indonesia and Malaysia," Journal of Indonesian Islam 13, no. 1 (June 2, 2019): 21. 
were born and kyai, the pesantren's leader, teach them witchcraft knowledge. ${ }^{35}$ The teaching and learning practices of witchcraft in pesantren are held at a specific time. It is usually held on Thursday night and the $10^{\text {th }}$ day of Muharram. There are numerous sorts of magical practices held by santri (who will be jawara) in pesantren salafi. Those mystical rituals are supervised by a senior santri, ustad, or kyai. Hadiran, Ziyad, Kekebalan (invulnerability power), Putergiling, Wafaq, Rajah, and Hizib are the types of magical practices taught to jawara in pesantren. In this study, the researcher will go through some of the most prevalent magical powers found in pesantren:

\section{Ilmu Kebal (the Science of Invulnerability Power)}

Some people believe that the science of invulnerability (henceforth: Ilmu kebal) is identical with Black Magic. According to Cees van Dijk ${ }^{36}$, ilmu kebal is akin to the practice of magic both white and black. Ilmu Kebal was developed in the area of pesantren in Banten. Debus traditional attraction in Banten is one of the examples of Ilmu Kebal. One of the most famous debus attractions in Banten is the ability to be invulnerable to sharp weapons. Nowadays, debus is usually used for entertainment purposes or as one of the traditional attractions from Banten. Ilmu Kebal which is taught in pesantren has the purpose of protecting santri from dangerous things. Ilmu kebal as learned in pesantren is meant for good purpose. ${ }^{37}$ Despite its negative image, Ilmu Kebal which is taught in pesantren in Banten has a good purpose. One of them is to protect from the dangerous thing. Santri or jawara who learn that ability is prohibited to use it for bad purposes. However, during its practice, some of them use that ability for bad purposes. They usually use that ability after finishing their study at Pesantren.

Kyai Fahad said, to get the ability of invulnerability power from Kyai, a santri is usually given two choices. Those choices are 'Asak' or 'Atah'. Asak means when santri does not need to do fasting and wirid in order to get the power. They only need to give something for Kyai as mahar (dowry) in exchange for the power. Mahar means numbers of money or things that must be given to kyai as a condition in getting magical power, or becoming ahli hikmah, and dukun (shaman). ${ }^{38}$ The second is Atah. It means that jawara must do certain ritual such as fasting for several days. There are several types of fasting and ways to obtain ilmu kebal. The first is fasting. People usually do it in Ramadhan or in certain days. Some do it in three days, seven or fourty days. During the fasting days, a santri must do wirid in certain times.The second type of fasting is called as puasa mutih (white fasting). This is the ritual of fasting in which the people are not allowed to eat anything but rice, salt and mineral water. The third type is puasa mati geni. It is a ritual when someone is not allowed to talk to anybody from morning till the next morning (in 24 hours), and that person must stay in certain room all by him/herself to do wirid. Besides fasting, the rituals must also be done with wirid based on the total numbers and time that has been determined. In example, every $10^{\text {th }}$ night of Muharam, KH. N.A, a Kyai of Darul Falah Islamic Boarding School in Ciruas Banten, usually invites his santri who live in and around his pesantren to do wirid together. The wirid is usually started at 09:00 PM until 02:00 AM. After doing wirid, he will enter a special room and

35 Yanwar Pribadi, "Another Side of Islam In Banten: The Socio-Political Roles of Jawara during the New Order Era 1966-1998," Journal of Indonesian Islam 7, no. 2 (December 1, 2013): 314.

${ }^{36}$ Cees Van Dijk, Magic and Violence, Paper Presented at the 13th Annual Workshop European Social Science Java Network (ESSJN): Youth and Identity (Marseilles, 2002).

37 Humaeni, "The LocaL Tradition of Magical Practices in Banten Society."

38 Kyai Fahad, "Personal Communication" (Kresek, 2017). 
call his santri one bay one and ask them to come to that room just like what he did. In that room, he will do certain magical practices (knowledge) for his santri. One of the magical practices is Ilmu Kebal (immunity power to sharp weapons). This explanation is in line with Ayatollah Humaeni's ${ }^{39}$ research on The Local Tradition of Magical Practices in Banten Society.

Even though all santris do wirid, but not all of them will get magical powers from the kiyai. Kyai will only give that magical power to special persons that he thinks that person deserves to get that power. Before giving Ilmu kebal, Kyai usually hold the right hand of the santri to be filled with ijazah (filled with the certain power). At that time, if kyai thinks that it is the right santri to get the power, then he will read wirid and rub the santri's hand. 40 After finishing that process, then Kyai will take a machete to slice the skin of the santri's hand. After believing that the santri succeeded in passing the test of Ilmu Kebal, then he will suggest and give some advices to that santri to not use that power for bad purpose. Those are yearly activities done by santri in Salafi Pesantren in Banten.

\section{Ziyad, Jeblag, Jurujud}

Ziyad power, or known as Jeblag, Kontak, and Jurujud is one of the magical abilities owned by jawara in Banten. This type of magical practice is usually done by two or more people. Its purpose is to hurt (punch) a body from a distance. In a fighting, most of jawaras use this ability. The way to use it is by using their hands or giving an eye contact to attack their enemies. If that jawara is able to master that ability perfectly, they could turn and break a car. The highest level of this ability is called as jurujud. There are several types of magical knowledge that are taught in pesantren in Banten, and these magical practices are inherited from era to era. Some of magical abilities that are commonly used by Jawara for fighting are Kama Rasa, Tendet, Jeblag, Dua Tendet, Konci, Potong, Giles, Lewat, Colok, and Jurujud. Every magical ability has differences from one another. ${ }^{41}$ Moreover, these abilities are also used to handle an attack from somebody or any sharp weapons. Not anyone can master those abilities. Kyai will only give those powers to certain people, usually to those who are good in controlling their emotion mentally and physically. If the owners of the ability cannot use it wisely, they could be crazy.

\section{E. Wafaq}

Wafaq is usually written words in Arabic, Pegon Javanese, or Javanese. Those words are written on paper, cloth, or certain animal skins which are believed to have properties. The magical teacher or magician usually draws sources for wafaq from certain classical Arabic books that are commonly used for the purposes of making wafaq. To write a wafaq, a wisdom expert must first calculate the name, the day of birth, the month of birth, day of requesting the wafaq and the name of the parents. All these names are written in Arabic. Then, each letter is converted into numbers. These numbers are then added up or subtracted by a complicated calculation. After being calculated with a complicated calculation, the remaining numbers are then matched into the lauhil hayat table and the lauhil mamat table in the book (kitab) of hikmah.42

\footnotetext{
${ }^{39}$ Humaeni, "The LocaL Tradition of Magical Practices in Banten Society."

40 Kyai Mahrusillah, "Personal Communication," 2017.

41 “Risalah Majmu'atul Hikmah" (n.d.).

42 Humaeni, "Penggunaan Magic Dalam Politik Lokal Di Banten."
} 
Some also said that wafaq is a collection of constant numbers. Actually, it is one of the lessons in Mathematics. Mathematical science is a useful science and therefore it is allowed to be studied. However, the experts of hikmah do not know that wafaq is one of the sciences of mathematics. In Mathematics, it is known as the Magic Square, meanwhile in magic it is known as the Magical Square. Wafaq is actually made with the algebraic number formula. ${ }^{43}$

Wafaq is one of the transfer media used by jawaras in controlling their magical power. Wafaq has several purposes depending on the owner's need. One of the purposes is to give a higher charisma of the people so that they can be more respected by others. Wafaq can also be used to get love, and immune to sharp weapons. Besides, it can also be used as a media to be successful in business, etc. Wafaq itself usually appears in the form of a piece of paper, or in the form of goat and cow's leather. There are various types of wafaq. They are called as mutsallas, murabba', mukhammas, musaddas, musabba, mutsamman, mutassa'. Wafaq itself contains the verses of the al-Quran or asmaul husna that are usually written with gold ink or zafa'ran oil. The wafaq should be folded and covered with small plastic in order not to be moldy. Wafaq is different from amulet. Even though both have the same function, but they have a different form. Amulet can appear in any form. It could be in form of piece of paper, Keris, tiger's fangs, etc. While wafaq can only appear in the form of paper as a media for magical power.

Medication using the verses of the Quran is not strange in Muslim society. Many of them ask for healing to the kyai because it is mentioned in the Quran that Allah sends down medication to the kyai as explained in the surah al-Isrā verse 82:

And We send down from the Al Quran something that is an antidote and a mercy for those who believe and that Al Quran does not add to the wrongdoers other than harm. (QS. Al-Isra: 82)

Many scholars have explained several verses that could be used for medicinal purposes, including al-Būnī in his book al-Ma'ārif al-Kubrā. In his book, he explained several verses that could be used for healing. He also explained how to apply these verses with the addition of certain ingredients. 44

In the practice of wisdom, the media that is often used is in the form of prayer writing or verses of the Quran in the form of wafaq or rajah, wirid practice or dzikir. Wafaq, rajah and wirid in the practice of wisdom are only used as intermediaries or media, not goals. The drugs recommended by a doctor to his patient are used as wasilah or intermediary of treatment for a disease suffered by the patient. People who practice the wisdom must have full confidence that the source of that power is essentially from the Almighty Creator.

\section{F. Hizib}

Besides some of the magical abilities that have been mentioned above, pesantren in Banten also has wirid which appears in form of hizib for magical purposes. Hizib is usually taken from the book of Risalah Majmu'atul Hikmah or Dalail Khairot. ${ }^{45}$ Hizib in

${ }^{43}$ Herdi Maulana and Maisyarah Rahmi, "Penggunaan Rajah Dan Wafaq Sebagai Azimat Pelaris Dagangan Dalam Hukum Islam: Studi Kasus Pasar Berkat Di Loa Janan Ilir," Qonun: Jurnal Hukum Islam dan Perundang-undangan 1, no. 1 (2020).

${ }^{44}$ Imam Ahmad bin Ali Al- Bunni, Shams Al-Ma'ārifal-Kubrā (Bairut: Darul Fikr, 1985).

45 Humaeni, "The LocaL Tradition of Magical Practices in Banten Society." 
Arabic means party, troops, or army. In this term, Hizib means specific long prayers. Most people named it amalan-amalan (prayers). Hizib is one of the prayers on which owners cannot count on. It is used when they against their enemies. Jawara commonly read this hizib when they are in trouble, for example when their enemies sent witchcraft for them. There are different types of Hizib given from Kyai to their jawara or santris. The types of hizib that are taught in pesantren are as follows: Hizib Nashr, Hizib Bahr, Hizib Ikhfa, Jailani Hizib, Hizib Yamani, Hizib Autad, Hizib Khafiy, Barqi and Hizib Nawawi. 46

Hizib is some prayers or wirid to glorify divine power that is often carried out by kyai, jawara or santri to obtain certain supernatural powers such as hizib Bagdad Jaelani, Asror, Rifai, Khoufi, Barqi, Nasor, and Isim Tunggal. Each hizib also contains certain levels depending on the series of orders that have been carried out. The higher the level of the hizib, the heavier the challenges faced in passing out the level. The method of obtaining abilities through hizib is what ultimately divides the two typical kyai; kyai kitab (who is well known in the local language as kiai bale rombeng) and kyai hikmah. Kyai hikmah is the one who focuses on carrying out certain tarekat to obtain supra-natural abilities, while kyai kitab focuses more on the orientation of the da'wah.47

During its process, magical powers gained by jawara and santri do not only come from pesantren, but they also get it from different sources other than pesantren. For example, witchcraft power, this magical ability comes from black magic. The black magic that comes from ancient Banten belief is named Jangjawoken or Rawayan. Therefore, during its process, many jawara were contaminated by the practice of Rawayan black magic. During its ritual, we will see many Jawara combining the ritual of religion and the practice of Jangjawoken. Jawara usually use witchcraft to hurt their enemies. It is usually done in the middle of the night. Witchcraft is one of black magic abilities that is usually used to kill enemies. This type of black magic is also called guna-guna. Witchcraft usually appears in the form of a flying fireball which is sent in the middle of the night. While the contents inside the witchcraft itself are usually sharp weapons such as nails, razor blades, shards, etc. The writers confessed it by themself of how witchcraft flew over a hose of a kyai in Banten. The areas which are famous for witchcraft and black magic are Lebak, Kanekes, Bojonegoro, Walantaka, Cikande, Petir, and some areas in Tangerang such as Pala Sari, Legok and Kresek. Witchcraft is usually sent in the evening around at 19:00 - 23:00 PM. If that witchcraft is sent over that time, it could be confirmed that the witchcraft fails to operate. What makes that thing happen? That happened because the power of witchcraft cannot work if it crosses the night fog. Therefore, 19:00 - 23:00 PM is the perfect time to send the witchcraft, where the night fog has not appeared yet. The writers confessed while witchcraft fell to one of a kyai's house in Banten. Baduy is one of the areas in Banten that is famous for its witchcraft. Baduy is also considered as the center of Black Magic in Banten.

The emergence of magical practices around pesantren in Banten becomes the power and also the source of Magic for most of the santri in Banten. Having magical power for Jawara in Banten became a necessity in the $18^{\text {th }}$ century, where they had to protect their area from the Dutch colonialism. The situation was getting worse when Banten Sultanate was collapsed and Ulama were eradicated from Banten Sultanate and government. Pressures from Dutch colonials toward local citizens triggered the rebellions against Dutch colonial. Therefore, the practices of magic that were taught in

46 "Risalah Majmu'atul Hikmah."

47 Asep Muslim and Dkk, "Dinamika Peran Sosial Politik Ulama Dan Jawara Di Pandeglang Banten," Mimbar 13, no. 2 (2015). 
most of pesantren in Banten were useful to fight against Dutch colonial. During the colonialism era, kyai and santri had a central role 48 in the rebellions in Banten. Almost every rebellion that happened in Banten was led by Kyai and Santri. In this situation, santri had a role as kyai's helper in doing rebellion activities. During the colonialism era, physical contact was the only solution to fight against Dutch colonialism.

\section{G. Conclusion}

Based on the explanation above, it can be concluded that most of the pesantren in Banten have their own uniqueness which make them different compare to any other pesantren in Indonesia. One of the uniqueness is that most of the pesantren in Banten teach martial art which is known as Silat, and also magical power. Pesantern in Banten is an educational institution that has been blended with its local cultures. The acculturation between local cultures and pesantren cannot be separated. The educational methods in pesantren in Banten focus on Tasawuf knowledge, which can be seen from its Santri's daily life. Magic is a legacy of local tradition that may be found around pesantren in Banten. While The transmission of Kanuragan power from kyai to their santri demonstrates magical activities. The transmission of magical power is now a common practice in santri's daily life

\section{H. Acknowledgments}

The authors would like to thank everyone who was involved from the beginning until the end of the process. This includes our colleagues who gave feedbacks, as well as the editorial board and the reviewers who handled the manuscript and provided valuable insights in improving it further.

\section{Author Contributions Statement}

All of authors worked together on the idea and the problem related to the topic. FI and AHA developed the theory. Furthermore, AS and HM verified the analytical methods. Then all of authors investigated and supervised the findings of this work. All of authors discussed the results and contributed to the final manuscript[.]

\section{REFERENCES}

Abdallah, Abdallah. "State, Religious Education, and Prevention of Violent Extremism in Southeast Asia." Studia Islamika 26, no. 2 (August 13, 2019). Accessed October 29, 2021. http://journal.uinjkt.ac.id/index.php/studiaislamika/article/view/12204.

Bruinessen, Martin Van. Kitab Kuning, Pesantren Dan Tarekat. Yogyakarta, Gading Publising, 2015.

Bunni, Imam Ahmad bin Ali Al-. Manba' Ushul Hikmah. Bairut: Darul Fikr, n.d.

Bunni, Imam Ahmad bin Ali Al-. Shams Al-Ma'ārif al-Kubrā. Bairut: Darul Fikr, 1985.

Davies, Sharyn Graham. "Gender and Power in Indonesian Islam: Leaders, Feminists, Sufis and Pesantren Selves." Theology \& Sexuality 22, no. 1-2 (May 16, 2016): 128130.

Dhavamony, Mariasusai. Fenomenologi Agama. Kelompok S. Yogyakarta: Kanisius, 1995.

48 Sharyn Graham Davies, “Gender and Power in Indonesian Islam: Leaders, Feminists, Sufis and Pesantren Selves," Theology \& Sexuality 22, no. 1-2 (May 16, 2016): 128-130. 
Dhofer, Zamakhsyari. “Tradisi Pesantren: Studi Pandangan Hidup Kiai Dan Visinya Mengenai Masa Depan Indonesia." (Jakarta: LP3ES) (2011).

Dijk, Cees Van. Magic and Violence. Paper Presented at the 13th Annual Workshop European Social Science Java Network (ESSJN): Youth and Identity. Marseilles, 2002.

Fahad, Kyai. "Personal Communication," 2017.

Fauzi, Muhammad Latif. "Traditional Islam in Javanese Society: The Roles of Kyai and Pesantren in Preserving Islamic Tradition and Negotiating Modernity." Journal Of Indonesian Islam 6, no. 1 (June 1, 2012): 125.

Gazali, Hatim, and Abd. Malik. "Pesantren and the Freedom of Thinking: Study of Ma'had Aly Pesantren Sukorejo Situbondo, East Java, Indonesia." Al-Jami'ah: Journal of Islamic Studies 47, no. 2 (December 20, 2009): 295-316.

Hambali. "Pengetahuan Mistis Dalam Konteks Islam Dan Filsafat Ilmu Pengetahuan." Substantia: Jurnal Ilmu-Ilmu Ushuluddin 13, no. 02 (2011).

Hood, Ralph W., and Daniel Lawrence O'Keefe. "Stolen Lightning: The Social Theory of Magic." Sociological Analysis (1982).

Hudaeri, Mohamad. “Tasbih dan Golok." Alqalam (2003).

Humaeni, Ayatullah. "Penggunaan Magic Dalam Politik Lokal Di Banten." Masyarakat, Kebudayaan dan Politik (2014).

Humaeni, Ayatullah. "The Basic Concepts of Magic And The Kinds of Magic in Banten Society." Al-Fath 03, no. 01 (2009).

Humaeni, Ayatullah. "The LocaL Tradition of Magical Practices in Banten Society." ElHarakah (2012).

Irfani, Fahmi. "Islam Dan Budaya Banten." Buletin Al-Turas 16, no. 1 (2010): 202-203.

Irfani, Fahmi. "Jawara Banten, Sebuah Kajian Sosial, Politik Dan Budaya." UIN Syarif Hidayatullah, 2011.

Isbah, M. Falikul. "Pesantren in the Changing Indonesian Context: History and Current Developments." QIJIS (Qudus International Journal of Islamic Studies) 8, no. 1 (June 22, 2020): 65.

Jamhari, Jamhari. "New Trend of Islamic Education in Indonesia." Studia Islamika 16, no. 2 (August 31, 2009). Accessed October 29, 2021. http://journal.uinjkt.ac.id/index.php/studia-islamika/article/view/482.

John, Mulhollanc. "Magic." The World Encyclopedia. Field Enterprises Educational Corp, 1964.

Koentjaraningrat. Beberapa Pokok Antropologi Sosial. Jakarta: Dian Rakyat, 1985.

Koentjaraningrat. "'Manusia Dan Kebudayaan Di Indonesia.'” Djambatan (2010).

Kuntowijoyo. "Pengantar Ilmu Sejarah." Jurnal Ilmu Sejarah dan Kebudayaan (2013).

Lukens-Bull, Ronald. "Madrasa By Any Other Name: Pondok, Pesantren, and Islamic Schools in Indonesia and Larger Southeast Asian Region." Journal of Indonesian Islam 4, no. 1 (June 1, 2010): 1.

Mahrusillah, Kyai. “Personal Communication," 2017.

Mas'ud, Ali, Ah. Zaki Fuad, and Achmad Zaini. "Evolution and Orientation of Islamic Education in Indonesia and Malaysia." Journal Of Indonesian Islam 13, no. 1 (June 2, 2019): 21.

Maulana, Herdi, and Maisyarah Rahmi. "Penggunaan Rajah Dan Wafaq Sebagai Azimat Pelaris Dagangan Dalam Hukum Islam: Studi Kasus Pasar Berkat Di Loa Janan Ilir." Qonun: Jurnal Hukum Islam dan Perundang-undangan 1, no. 1 (2020).

Mauss, Marcel. A General Theory of Magic. New York: W.W. Norton \& Company, 1975.

Muqoyyidin, Andik Wahyun. "Islam Jawa, Distingsi Tradisi, Transformasi Spirit Profetik, Dan Globalisasi." Akademika: Jurnal Pemikiran Islam 21, no. 1 (2016). https:// e-journal.metrouniv.ac.id/index.php/akademika/article/view/458. 
Muslim, Asep, and Dkk. "Dinamika Peran Sosial Politik Ulama Dan Jawara Di Pandeglang Banten." Mimbar 13, no. 2 (2015).

Nafisah, Siti Durrotun. "Melacak Sumber-Sumber Penggunaan Ayat-Ayat Pengobatan Dalam Kitab Shams Al-Ma'ārif Al-Kubrā." Al Itqon: Jurnal Studi Al-Qur'an 5, no. 1 (2019).

Peursen, C.A. van. Strategi Kebudayaan. Yogyakarta: Kanisius, 1988.

Pranoto, Ki Agung. Saatnya Dukun Bicara: Tinjauan Kritis Terhadap Takhayul Dan Kebatinan. Yogyakarta: Galang Press, 2000.

Pribadi, Yanwar. "Another Side of Islam in Banten: The Socio-Political Roles of Jawara during the New Order Era 1966-1998." Journal Of Indonesian Islam 7, no. 2 (December 1, 2013): 314.

Pribadi, Yanwar. "Pesantren Pluralis: Peran Pesantren Ngalah Dalam Mengembangkan Nilai-Nilai Pluralisme Di Tengah Masyarakat Yang Multikultural, by M. Muntahibun Nafis." Bijdragen tot de taal-, land-en volkenkunde / Journal of the Humanities and Social Sciences of Southeast Asia 174, no. 2-3 (January 1, 2018): 333337.

Provencher, Ronald, Ahmad Ibrahim, Sharon Siddique, Yasmin Hussain, and Taufik Abdallah. "Readings on Islam in Southeast Asia." Journal of the American Oriental Society (1990).

Rawls, John, Bronislaw Malinowski, and Robert Redfield. "Magic, Science, and Religion and Other Essays." The Philosophical Review (1948).

Rohman. "The Result of a Holy Alliance: Debus and Tariqah in Banten Province." Afkaruna: Jurnal Ilmu-Ilmu Keislaman 9, no. 1 (2013).

Shadily (ed.), Hasan. “Magi." Ensiklopedi Nasional Indonesia. Cipta Adi Pustaka, 1990.

Tihami, M.A. "Kiyai Dan Jawara Di Banten, Studi Tentang Agama, Magi, Dan Kepemimpinan Di Desa Pesanggrahan Serang Banten." University of Indonesia, 1992.

Tihami, M.A. “Kyai Dan Jawara Di Banten.” Indonesia University, 1991.

UIN Jakarta, Tim PPIM. "Strengthening Civic Values Through Pesantren and Madrasah." Studia Islamika 15, no. 2 (August 31, 2008). Accessed October 29, 2021. http://journal.uinjkt.ac.id/index.php/studia-islamika/article/view/535. 